\title{
HUBUNGAN TINGKAT PENGETAHUAN IBU TERHADAP PERKEMBANGAN MOTORIK HALUS ANAK PRASEKOLAH DI TK TUNAS MEKAR I
}

\author{
Kadek Sri Ariyanti, S.SiT.,M.Kes ${ }^{1}$,Lakitha Ning Utami, S.SiT ${ }^{2}$ \\ ${ }^{1}$ Program Studi Diploma III Kebidanan, STIKES Advaita Medika Tabanan \\ Email : ariyanthi.midwife@gmail.com
}

\begin{abstract}
Abstrak
Latar belakang dan tujuan: Perkembangan fisik yang dapat dilihat pada anak adalah perkembangan motorik halus yang berkesinambungan sesuai dengan usia anak dan berkaitan dengan perkembangan otak anak. Oleh karena itu pendidikan seorang ibu sangat berperan penting dalam mengasuh anak terutama dalam tahap perkembangan anaknya. Pengetahuan ibu yang baik akan menghasilkan anak yang sehat dan perkembangannya sesuai dengan umurnya. Tujuan penelitian ini adalah untuk mengetahui hubungan tingkat pengetahuan ibu terhadap perkembangan motorik halus anak prasekolah dan untuk mengetahui gambaran karakteristik ibu serta tingkat pengetahuan ibu.

Metode: Penelitian ini adalah metode penelitian korelatif dengan pendekatan subjek cross sectional yang dilaksanakan di TK Tunas Mekar 1 Desa Tegaljadi Marga Tabanan. Populasi penelitian ini adalah semua anak prasekolah di TK tersebut yang jumlahnya 60 orang. Tehnik sampling yang digunakan adalah total sampling. Teknik analisis data yang digunakan adalah analisa korelasi bivariate (Chi Square).

Hasil: Hasil analisis data menunjukkan bahwa nilai Chi kuadrat $\left(\chi^{2}\right)$ hitung sebesar 36,923. Hal ini berarti bahwa ada hubungan yang signifikan antara variabel pengetahuan ibu terhadap variabel perkembangan motorik halus anak prasekolah. Selanjutnya nilai koefisien kontingensi (C) adalah sebesar 0,617 yang termasuk dalam kategori hubungan yang kuat.

Simpulan: ada hubungan yang signifikan antara variabel pengetahuan ibu terhadap variabel perkembangan motorik halus anak prasekolah di TK Tunas Mekar 1 Desa Tegaljadi, Marga, Tabanan.
\end{abstract}

Kata Kunci : pengetahuan ibu, perkembangan motorik halus, usia prasekolah

\section{PENDAHULUAN}

Pembangunan kesehatan sebagai bagian dari upaya membangun manusia seutuhnya antara lain diselenggarakan melalui upaya kesehatan anak yang dilakukan sedini mungkin sejak anak masih di dalam kandungan. Untuk mempersiapkan SDM yang berkualitas dimasa yang akan datang, maka anak perlu dipersiapkan agar dapat tumbuh dan berkembang seoptimal mungkin sesuai dengan kemampuannya (Narendra, 2008).

Tumbuh kembang dikatakan terlambat jika seorang anak tidak mencapai tahap pertumbuhan dan perkembangan yang diharapkan pada umur yang semestinya, dengan ketertinggalan dalam populasi yang normal (Sacker, 2011). Prevalensi keterlambatan di suatu populasi sangat bervariasi, studi yang dilakukan Dudley mencatat $3,3 \%,-17 \%$ anak mengalami keterlambatan (Dudley, 2010).

Anak merupakan penentu kualitas Sumber Daya Manusia (SDM) dimasa yang akan datang, untuk itu perlu dipersiapkan dengan baik agar tumbuh dan berkembang seoptimal mungkin. Proses tumbuh kembang 
merupakan proses yang berkesinambungan mulai dari konsepsi sampai dewasa meliputi pola tertentu yang khas untuk setiap anak.Pertumbuhan dan perkembangan anak merupakan hasil interaksi antara faktor genetik dengan faktor lingkungan fisik serta biopsiko sosial. Anak usia prasekolah adalah masa keemasan (golden age) yang mempunyai arti penting dan berharga karena masa ini merupakan pondasi bagi masa depan anak dan masa rentan terhadap berbagai perubahan fisik dan psikososial dimana dalam masa ini anak mempunyai sifat imitasi/mudah meniru terhadap apapun yang dilihat (Nuraeni, 2006).

Salah satu bentuk stimulasi dasar untuk tumbuh kembang anak adalah asah yang mengembangkan perkembangan mental psikososial diantaranya, kecerdasan, keterampilan, kemandirian, kreatifitas, kepribadian, moral etika. Dengan mengasah kemampuan anak secara terus menerus, kemampuan anak semakin meningkat (Soetjiningsih, 2002).

Aspek perkembangan merupakan aspek yang menjelaskan proses pembentukan seseorang secara psikososial. Namun dalam era globalisasi ini ibu yang pengetahuannya kurang atau ibu yang mempunyai anak prasekolah menyebabkan kurangnya kemampuan ibu untuk mengasah kemampuan dasar anaknya. Mereka yang menganggap bahwa selama anak tidak sakit, berarti anak tidak mengalami masalah. Sering kali orang tua hanya memperhatikan aspek pertumbuhannya saja dan mengabaikan aspek perkembangannya (Nursalam, 2004).

Salah satu perkembangan fisik yang dapat dilihat pada anak adalah perkembangan motorik halus. Perkembangan motorik ini berkesinambungan sesuai dengan usia anak dan berkaitan dengan perkembangan otak anak. Perkembangan motorik halus adalah aktifitas motorik halus yang hanya melibatkan bagian tubuh tertentu dan dilakukan oleh otot kecil yang tidak memerlukan tenaga, tetapi memerlukan koordinasi yang cukup. Apabila perkembangan otot tidak bagus kemungkinan besar perkembangannya pun tidak berjalan dengan normal. \begin{tabular}{lcrr}
\multicolumn{2}{c}{ Tumbuh } & kembang & \multicolumn{2}{r}{ dikatakan } \\
terlambat jika & seorang anak & tidak \\
mencapai & tahap & pertumbuhan & dan
\end{tabular} perkembangan yang diharapkan pada umur yang semestinya, dengan ketertinggalan dalam populasi yang normal (Sacker, 2011). Prevalensi keterlambatan di suatu populasi sangat bervariasi, studi yang dilakukan Dudley mencatat 3,3\%,-17\% anak mengalami keterlambatan (Dudley, 2010).

Kemampuan motorik merupakan salah satu proses tumbuh kembang yang harus dilalui dalam kehidupan anak, baik motorik halus maupun motorik kasar (Kartika, 2002). Seringkali orang tua lebih terfokus pada perkembangan motorik kasar saja, padahal perkembangan motorik kasar merupakan indikator yang tidak sensitif dalam hal kemampuan mental keseluruhan (Alpers, 2006).

Penelitian yang dilakukan di Equador pada anak 48-61 bulan tahun 2003-2004, tercatat $28,1 \%$ anak mengalami keterlambatan motorik halus (Handal, 2007). Sedangkan dari jurnal penelitian Indonesia yang diambil dari dua rumah sakit di Jakarta menyebutkan bahwa 11,3\% anak mengalami keterlambatan perkembangan motorik halus (Widyastuti, 2005).

Pertumbuhan dan perkembangan anak dipengaruhi oleh pemenuhan gizi yang cukup. Air Susu Ibu (ASI) merupakan makanan terbaik pada masa bayi karena mengandung semua bahan yang diperlukan oleh bayi. Anak yang mendapatkan ASI eksklusif pertumbuhan dan perkembangannya lebih baik dan terhindar dari obesitas. Frekuensi menyusui sesering mungkin pada bayi berusia enam bulan pertama terbukti sangat bermanfaat, karena volume ASI yang dihasilkan lebih banyak, sehingga mencegah penurunan berat badan bayi.Agar perkembangan stimulus anak berkembang dengan baik dari fisik maupun mentalnya harus memiliki hubungan yang dekat dengan ibunya (Nursalam, 2005).

Di poliklinik tumbuh kembang anak pada Badan Layanan Umum Rumah Sakit Sanglah Denpasar melaporkan paa tahun 2011 terdapat 
7.482 kunjungan anak balita yang dilakukan pemeriksaan perkembangannya dengan media Denver Development Screening Test (DDST) karena keluhan keterlambatan perkembangan meliputi perkembangan sosial, basa, motorik kasar, dan motorik halus, sebanyak 358 orang anak balita mengalami gagal perkembangan dimana 126 orang anak mengalami gangguan motorik halus, 70 orang anak mengalami gangguan motorik kasar, 76 orang yang mengalami gangguan bahasa, dan 86 orang anak mengalami gangguan personal sosial.

Berdasarkan pengalaman dalam kehidupan sehari-hari, anak yang diasuh oleh ibu yang mempunyai latar belakang pendidikan yang baik, mempunyai perkembangan yang baik. Salah satu contohnya adalah dalam pemberian imunisasi dan ASI Ekseklusif. Ibu yang pengetahuannya baik akan mengerti manfaat imunisasi dan pemberian ASI Ekseklusif untuk perkembangan anak nantinya. Sedangkan ibu yang pengetahuannya kurang, kadang-kadang tidak mengerti akan kebutuhan anaknya dan tidak memahami apa yang diperlukan anaknya seperti pemberian imunisasi dan ASI Ekseklusif.

Terkait dengan masalah perkembangan motorik halus pada anak-anak prasekolah, Rini (2009) dalam penelitiannya yang mengkaji perkembangan motorik halus berdasarkan usia anak menemukan bahwa perkembangan motorik halus pada anak-anak prasekolah TK Kartini I tidak sesuai dengan standar ukuran yang menjadi patokan penilaian normal atau tidaknya perkembangan motorik halus anak. Sedangkan penelitian ini secara khusus menguji hubungan variabel pengetahuan ibu pada perkembangan motorik halus anak prasekolah.

Hasil studi pendahuluan yang dilakukan di TK Tunas Mekar I Desa Tegaljadi wilayah kerja Puskesmas Marga II pada bulan Mei 2016 diketahui bahwa 60 orang anak usia 4 - 6 tahun yang bersekolah di TK Tunas Mekar I sebanyak 45 anak (75\%) yang ibunya hanya tamat SD dan SMP. Berasarkan hasil wawancara di sekolah tersebut tidak pernah diberikannya stimulus perkembangan mental pada anak hanya melihat bisa atau tidaknya anak tersebut mengikuti pelajaran yang diberikan oleh gurunya, salah satu guru di sekolah TK tersebut mengatakan bahwa ada 2 orang anak yang tidak dapat mengikuti pelajaran dan dikeluarkan dari sekolah karena mengalami keterlambatan Down syndrome, dimana dari data dijelaskan bahwa anak tersebut tidak mendapatkan imunisasi dan ASI Ekseklusif dan ibunya hanya tamat SD.

Anak akan berkembang terus secara bertahap sesuai dengan usia perkembangannya. Dengan memberikan stimulus atau mengasah (pendidikan dan pelatihan) kemampuan anak dirumah dengan cara mengajak anak bermain, bercerita atau mendongeng, berbuat baik, dan bagaimana memecahkan suatu masalah, maka perkembangan anak tersebut perkembangannya lebih baik dari pada yang tidak mendapatkan stimulasi sehingga dapat menghasilkan anak dengan kepribadian yang kuat, mandiri, tidak mudah putus asa, dan tidak cemas, santun dan peduli terhadap orang lain dan lingkungannya. Agar perkembangan stimulus anak berkembang dengan baik dari fisik maupun mentalnya harus memiliki hubungan yang dekat dengan ibunya (Nursalam, 2005).

Ibu atau orang tua harus mampu menstimulasi kemampuan perkembangan anak agar tumbuh dan berkembang dengan baik secara fisik, mental, dan psikologis karena pada usia prasekolah terjadi peningkatan pergerakan dan keingintahuan keadaan sekitar, adanya peningkatan pengertian kognitif dan kemampuan komunikasi. Oleh karena itu pendidikan seorang ibu sangat berperan penting dalam mengasuh anak terutama dalam tahap perkembangan anaknya. Pengetahuan ibu yang baik akan menghasilkan anak yang sehat dan perkembangannya sesuai dengan tingkatan umurnya. Untuk tenaga kesehatan / tenaga terlatih agar rutin melakukan stimulus deteksi dini tumbuh kembang pada anak, dan mengajak para ibu untuk sedini mungkin memberikan stimulasi pada anaknya. Memahami pentingnya peran ibu dalam tumbuh kembang anak maka penelitian untuk menguji hubungan tingkat pengetahuan ibu 
terhadap perkembangan motorik halus anak prasekolah menjadi penting untuk dilakukan.

\section{METODE PENELITIAN}

Penelitian ini adalah metode penelitian korelatif yang mengkaji antara dua variabel yaitu variabel independen dan variabel dependen. Model pendekatan subjek yang digunakan cross sectional yang memberikan gambaran tingkat pengetahuan ibu terhadap perkembangan anak prasekolah.

Populasi adalah semua subyek atau individu yang memiliki karakteristik tertentu, jelas dan lengkap (Notoadmojo,2003). Dalam penelitian ini populasinya adalah semua anak prasekolah di Taman Kanak-Kanak Tunas Mekar I Desa Tegaljadi, Marga, Tabanan. Populasi yang ada saat stadi pendahuluan adalah 60 orang dimana 30 orang ibunya tamat SD dan SMP.

Sampel penelitian ini adalah anak prasekolah usia 4-6 tahun yang bersekolah di Taman Kanak-Kanak Tunas Mekar I Tegaljadi yang memenuhi kriterea sebagai berikut:

1) Kriteria inklusi:

a. Ibu yang bersedia anaknya untuk diteliti dengan menandatangani lembar persetujuan penelitian.

b. Anak umur 4-6 tahun.

c. Anak yang bersekolah di Taman Kanak-Kanak Tunas Mekar I Tegaljadi dalam kurun waktu dilakukan penelitian yaitu bulan Mei 2016.

2) Kriteria Eksklusi

a. Anak tidak masuk sekolah

b. Tidak bersedia jadi responden

Sampling adalah tehnik yang digunakan dalam pengambilan sampel tersebut sedapat mungkin mewakili populasi (Notoatmojo, 2010). Pada penelitian ini tehnik sampling yang digunakan adalah total sampling yaitu dengan memilih semua anak yang ada di Taman Kanak-Kanak Tunas Mekar I Tegaljadi yang memenuhi kriteria insklusi dan diijinkan menjadi responden sampai besar sampel masing-masing katagori yang ditetapkan. Besar sampel sesuai dengan yang dikemikakan Roscoe, (2007). Bila sampel dibagi dalam katagori maka jumlah sampel masing-masing katagori minimal 30 sampel sehingga besar sampel seluruhnya minimal 60 sampel.Pada penelitian ini besar sampel yang memenuhi kriteria yaitu 60 sampel.

Penelitian dilaksanakan di Taman KanakKanak Tunas Mekar 1 Desa Tegaljadi Marga Tabanan pada bulan Mei 2016. Lokasi ini dipilih atas pertimbangan :

1. Tersedia populasi yaitu anak umur $4-6$ tahun

2. Jumlah keseluruhan anak yang berumur 4-6 tahun dapat digunakan sebagai kelompok penelitian

3. Mudah dijangkau oleh peneliti

4. Belum pernah dilakukan penelitian yang sama sebelumnya

Untuk mengumpulkan data, peneliti menggunakan sumber data primer pada bulan Mei 2015. Pada penelitian ini cara pengumpulan data yang digunakan adalah lembar Koesioner, lembar observasi dan lembar DDST.

Penelitian ini merupakan jenis penelitian Korelasional maka setelah data dikumpulkan dan data diperiksa, kemudian dilakukan analisa data dengan menggunakan uji statistik yaitu statistik non parametric yaitu Chi kuadrat $\left(\chi^{2}\right)$.

Prosedur perhitungan uji statistik non parametric Chi kuadrat adalah sebagai berikut:

1. Menghitung harga Chi kuadrat

Dengan menggunakan rumus

$$
x^{2}=\sum \frac{(f o-f h)}{f h}
$$

Keterangan :

(Sugiyono,2010).

$\chi^{2}=$ Chi kuadrat

fo $=$ frekuensi yang diobservasi

$\mathrm{fh}=$ frekuensi yang diharapkan

2. Cari Chi Kuadrat Tabel.

Untuk mencari Chi kuadrat tabel, harus menentukan dk dan taraf kesalahan tertentu (pada penelitian ini menggunakan taraf kesalahan $\alpha=0,05$ $(95 \%)$. Harga dk dicari dengan menggunakan rumus:

$\mathrm{Dk}=(\mathrm{k}-1)(\mathrm{r}-1)$

Keterangan

$\mathrm{r}=$ jumlak kelompok sampel 
$\mathrm{k}$ = banyak kategori dalam sampel

Setelah mendapatkan dk, maka cari nilai Chi kuadrat. Pada table Chi kuadrat dengan $\alpha=0,05 \quad(95 \%)$. (Sugiyono,2010)

\section{HASIL DAN PEMBAHASAN}

Penelitian ini dilaksanakan di Taman Kanak-Kanak Tunas Mekar 1 Desa Tegaljadi, Kecamatan Marga, Kabupaten Tabanan, Propinsi Bali karena satu-satunya TK yang memenuhi kriteria responden untuk dilakukan penelitian.

Umur individu yang terhitung mulai saat dilahirkan sampai berulang tahun dan cukup umur (Nursalam, 2003). Berdasarkan rekapitulasi data penelitian yang diperoleh dari 60 responden ibu dan anak usia pra sekolah, maka diperoleh data ibu dengan usia kurang dari 20 tahun sebanyak 2 orang (3,3 $\%$ ), ibu dengan usia 20 sampai 35 tahun sebanyak 56 orang $(93,3 \%)$ dan ibu dengan usia di atas 35 ahun sebanyak 2 orang (3,3\%). Data memperlihatkan bahwa mayoritas ibu berusia antara 20 sampai 35 tahun. Berdasarkan umur dan tingkat pengetahuan ibu maka ada pengaruh yang signifikan terhadap perkembangan motorik halus anak prasekolah.

Bimbingan yang diberikan seseorang terhadap perkembangan orang lain menuju kearah cita-cita yang menentukan manusia untuk berbuat dan mengisi kehidupan (Notoatmojo, 2003). Maka pendidikan seorang ibu bisa sama tapi pengetahuannya berbeda. Berdasarkan rekapitulasi data penelitian yang diperoleh dari 60 responden ibu dan anak usia pra sekolah, maka diperoleh data ibu dengan pendidikan terakhir SD sebanyak 6 orang $(10 \%)$, ibu dengan pendidikan SMP sebanyak 18 orang (30\%), ibu dengan pendidikan SMA/SMK sebanyak 32 orang $(53,3 \%)$ dan ibu dengan pendidikan Akademi / Perguruan Tinggi sebanyak 4 orang $(6,7 \%)$. Data memperlihatkan bahwa mayoritas ibu memiliki pendidikan terakhir SMA/SMK.

Pendidikan merupakan upaya manusia untuk mendapatkan pengalaman berupa penambahan pengetahuan. Seiring dengan meningkatnya jenjang pendidikan yang ditempuh berkembang pula kedewasaan dan kemampuan seseorang untuk menyerap dan mencernah informasi yang didapat (Ahira, 2011). Makin tinggi pendidikan seseorang, maka makin mudah menerima informasi sehingga makin banyak pula pengetahuan yang dimiliki. Pendidikan berarti bimbingan yang diberikan seseorang terhadap perkembangan orang lain menuju kearah citacita tertentu yang menentukan manusia untuk berbuat dan mengisi kehidupan untuk mencapai keselamatan dan kebahagiaan. Pendidikan diperlukan untuk mendapat informasi misalnya hal-hal yang menunjang kesehatan sehingga dapat meningkatkan kualitas hidup. Pendidikan dapat mempengaruhi seseorang termasuk juga. perilaku seseorang akan pola hidup terutama dalam memotivasi untuk sikap berperan serta dalam pembangunan. Pada umumnya makin tinggi pendidikan seseorang makin mudah menerima informasi (Wawan, dkk, 2010).

Menurut Hendra (2012) pendidikan merupakan proses pengubahan sikap dan tata laku seseorang atau kelompok orang dalam usaha mendewasakan manusia melalui upaya pengajaran dan pelatihan atau proses perubahan dan cara pendidikan. Makin tinggi tingkat pendidikan seseorang makin mudah menerima informasi. Sehingga dapat disimpulkan bahwa fakta sesuai dengan teori (Wawan,dkk,2010) yang telah diungkapkan diatas bahwa responden yang berpendidikan tinggi akan mudah dalam menyerap informasi tentang perkembangan motorik kasar pada anak usia pra sekolah, sehingga pengetahuan tentang perkembangan motorik kasar pada anak usia pra sekolah lebih baik. Namun sebaliknya, responden yang berpendidikan rendah akan mengalami hambatan dalam penyerapan informasi tentang perkembangan motorik kasar pada anak usia pra sekolah sehingga pengetahuan tentang perkembangan motorik kasar pada anak usia pra sekolah juga lebih rendah. Hasil penelitian menunjukkan bahwa sebagian besar responden berpendidikan SD, dengan demikian pengetahuan responden tentang perkembangan 
motorik kasar pada anak usia pra sekolah kurang.

Kewajiban yang harus dilakukan untuk menunjang kehidupan dan kehidupan keluarga. Dengan pengetahuan yang dimiliki seorang ibu juga berpengaruh terhadap pekerjaan yang didapatkannya. Rekapitulasi data penelitian yang diperoleh dari 60 responden ibu dan anak usia pra sekolah, memperlihatkan data ibu dengan pekerjaan sebagai buruh / Tani sebanyak 28 orang $(46,7$ $\%$ ), ibu dengan pekerjaan pegawai swasta sebanyak 26 orang $(43,3 \%)$, ibu dengan pekerjaan wiraswasta sebanyak 2 orang $(3,3$ $\%)$, dan ibu dengan pekerjaan sebagai PNS/POLRI/TNI sebanyak 4 orang $(6,7 \%)$. Data memperlihatkan bahwa mayoritas ibu memiliki pekerjaan sebagai buruh / tani dan pegawai swasta.

Berdasarkan rekapitulasi data jawaban responden (ibu) dari instrumen penelitian yang disebarkan kepada 60 responden, memperlihatkan bahwa ibu dengan pengetahuan kategori tinggi sebanyak 52 orang $(86,7 \%)$, dan ibu dengan pengetahuan kategori sedang sebanyak 8 orang $(13,3 \%)$. Data memperlihatkan bahwa jumlah ibu dengan pengetahuan kategori tinggi jauh lebih banyak dari pada ibu dengan pengetahuan kategori sedang, Sedangkan untuk pengetahuan kategori rendah tidak ada.

Pengetahuan dipengaruhi oleh usia reponden. Usia adalah umur individu yang terhitung mulai saat dilahirkan sampai berulang tahun. Semakin cukup urnur, tingkat kematangan dan kekuatan seseorang akan lebih matang dalam berfikir dan bekerja. Dari segi kepercayaan masyarakat seseorang yang lebih dewasa dipercaya dari orang yang belum tinggi kedewasaannya. Hal ini akan sebagai dari pengalaman dan kematangan jiwa (Wawan, dkk, 2010). Temuan data ini sesuai dengan pendapat Hendra (2012) yang menyatakan bahwa umur sangat berpengaruh pada pengetahuan dan kesadaran seseorang, semakin cukup umur seseorang maka tingkat kematangan dan kekuatan seseorang akan lebih matang dalam berfikir dan bertindak. Umur adalah lama waktu hidup atau sejak dilahirkan atau diadakan Pada batas umur tertentu, seseorang mengalami suatu perkembangan dalam proses kematangan. Terjadi proses fisiologis yang menyebabkan beberapa perubahan tertentu, baik kualitatif maupun kuantitatif yang bersifat fisiologis maupun psikologis. Hal ini sebagai akibat dari kematangan jiwanya dan berpengaruh terhadap pengetahuannya.

Dengan demikian responden yang berusia lebih dewasa akan lebih banyak memperoleh pengetahuan, pengalaman dan informasi tentang perkembangan motorik kasar pada anak usia pra sekolah daripada yang berumur lebih muda. Namun sebaliknya responden yang berumur lebih muda masih terbatas dalam berpikir saja tanpa mempunyai berpengaruh pada setiap keputusan dan tindakannya. Seharusnya semakin tua umur responden maka pengetahuan tentang perkembangan motorik kasar pada anak usia pra sekolah semakin bertambah pula. Keadaan ini disebabkan karena waktu untuk mendapatkan pengetahuan tentang perkembangan motorik kasar pada anak usia pra sekolah lebih lama. Akan tetapi hasil penelitian menunjukkan bahwa semakin tua responden tidak menunjukkan pengetahuannya menjadi lebih baik. Hal ini terbukti dengan hasil penelitian yang menunjukkan sebagian besar responden berpengetahuan kurang tentang perkembangan motorik kasar pada anak usia pra sekolah.

Selain itu, pengetahuan jika dikaitkan dengan jenjang pendidikan terakhir yang dimiliki oleh rata-rata keseluruhan responden yaitu jenjang SMA/SMK dan SMP, maka sangatlah wajar apabila tingkat pengetahuan para ibu ini berada pada kategori tinggi. Menurut Soekanto (2002), menyatakan bahwa pengetahuan merupakan kesan dalam pikiran sebagai hasil penggunaan panca indranya. Pengetahuan atau kognitif merupakan domain yang sangat penting bagi terbentuknya perilaku seseorang, pengetahuan akan merangsang terjadinya perubahan sikap bahkan tindakan seorang individu, pengetahuan tentang suatu objek dapat diperoleh dari pengalaman, guru, orang tua, dan media masa. Jadi ada pengaruh yang 
signifikan antara pengetahuan ibu dengan perkembangan motorik halus anak prasekolah.

Berdasarkan rekapitulasi data observasi perkembang motorik halus anak-anak usia pra sekolah yang diperoleh dari 60 responden, memperlihatkan bahwa anak dengan perkembangan motorik halus dalam kategori tidak optimal sebanyak 8 orang $(13,3 \%)$, dan anak dengan perkembangan motorik halus dalam kategori optimal sebanyak 52 orang $(86,7 \%)$.

Data memperlihatkan bahwa jumlah anak usia pra sekolah dengan perkembangan motorik halus dalam kategori optimal jauh lebih banyak dari pada anak usia dengan perkembangan motorik halus dalam kategori tidak optimal yang hanya berjumlah 8 dari 60 orang. Kondisi ini mengindikasikan bahwa anak yang mengalami perkembangan motorik halus kurang optimal masih relatif tinggi yaitu sebesar $13,3 \%$.

Menurut Soetjiningsih (2002), faktor yang dapat menghambat pertumbuhan dan perkembangan anak adalah kelahiran sulit (terutama apabila terjadi trauma pada kepala), anak dengan intelegensi yang rendah, orang tua yang terlalu protektif sehingga menghambat perkembangan anak untuk melakukan latihan-latihan motorik, kelahiran anak yang dini (prematur) serta lahir dengan cacat bawaan dan perbedaan pola asuh Untuk itu upaya-upaya dalam mengoptimalkan perkembangan motorik halus di Taman Kanak-Kanak Tunas Mekar I Desa Tegaljadi Marga Tabanan masih harus terus dilakukan.

Unsur-unsur yang berpengaruh dalam perkembangan anak adalah orang tua, keluarga, masyarakat, serta lingkungan tempat ia tumbuh dan berkembang. Interaksi anak dengan orang tua akan menimbulkan keakraban yang berpengaruh terhadap perkembangan anak yang tidak tertutup. Orang tua memegang perananterbesar dalam mendidik anak (Herlina, 2010).

Orang tua memiliki peran yang penting untuk merangsang potensi yg dimiliki oleh anak. Tugas pengasuhan umumnya diserahkan kepada ibu yang didasarkan pada pengetahuan yang dimilikinya. Salah satu faktor yang mempengaruhi pengetahuan adalah tingkat pendidikan ibu. Apabila ibu memiliki pengetahuan yang tinggi maka akan lebih aktif dalam mencari informasi untuk meningkatkan keterampilan dalam pengasuhan anak (Hastuti, 2010).

Berdasarkan analisis statistik dan pencarian dalam tabel Chi kuadrat $\left(\chi^{2}\right)$, maka diketahui nilai Chi kuadrat $\left(\chi^{2}\right)$ hitung sebesar 36,923 dan nilai Chi kuadrat $\left(\chi^{2}\right)$ tabel sebesar 3,481, sehingga dengan demikian nilai Chi kuadrat $\left(\chi^{2}\right)$ hitung > nilai Chi kuadrat $\left(\chi^{2}\right)$ tabel, dengan nilai koefisien kontingensi (C) adalah sebesar 0,617 dalam kategori kuat. Hal ini berarti Ho ditolak dan Ha diterima. Hasil pengujian hipotesis menunjukkan bahwa pengetahuan ibu berhubungan kuat dengan perkembangan motorik halus.

Menurut WHO pengetahuan atau kognitif merupakan domain yang sangat penting bagi terbentuknya perilaku seseorang, pengetahuan akan merangsang terjadinya perubahan sikap bahkan tindakan seorang individu, pengetahuan tentang suatu objek dapat diperoleh dari pengalaman, guru, orang tua, dan media masa.

Menurut Notoatmodjo (2006), aadapun faktor-faktor yang mempengaruhi tingkat pengetahuan yaitu umur, penidikan, informai, ekonomi/pekerjaan, pengalaman, budaya, intelegensi, dan lingkungan.

Menurut Soetjiningsih (2002) salah satu kebutuhan dasar anak adalah asah yang merupakan cikal bakal dalam proses belajar (pendidikan dan pelatihan ) pada anak. Stimulasi mental atau asah ini mengembangkan perkembangan mental psikososial diantaranya, kecerdasan, ketrampilan, kemandirian, kreatifitas, agama, kepribadian, moral etika.

Dalam penelitian ini yang dimaksud adalah tingkat pengetahuan ibu dalam mendidik anak yang mempunyai pengaruh besar dalam pertumbuhan dan perkembangan anaknya dimana ibu yang pengetahuannya baik mengasuh dan merawat anaknya sesuai dengan perawatan yang seharusnya didapatkan oleh seorang anak. Untuk mengetahui perkembangan yang sesuai dapat 
dilakukan dengan tes Denver Developmental Screening Test (DDST) yang bisa dilakukan dalam waktu 10-15 menit. Umumnya anak umur lima tahun pada perkembangan terlebih dititik beratkan pada sektor motorik halus sudah mampu menggambar manusia dalam tiga atau enam bagian besar, mampu menggambar persegi tanpa contoh, mampu menentukan garis yang lebih panjang, mampu memasang kancing baju sendiri tanpa bantuan (Gunarso dkk, 2004).

Untuk itu keterlibatan ibu-ibu dalam memantau dan melatih perkembangan motorik halus sangat dibutuhkan. Maka dari itu tugas melatih motorik halus tidak dapat hanya dibebankan kepada sekolah saja akan tetapi harus melibatkan partisipasi aktif dari ibu-ibu dalam pemantauan dan pelatihan.

\section{KESIIMPULAN}

Berdasarkan hasil analisis dan pembahasan terhadap hasil penelitian, maka dapat penulis simpulkan sebagai berikut :

1) Tingkat pengetahuan ibu tentang perkembangan anak prasekolah (4-6 tahun) termasuk dalam kategori tinggi sebanyak 52 orang $(86,7 \%)$ sedangkan untuk tingkat pengetahuan ibu dalam katagori sedang sebanyak 8 orang ( 13,3 $\%)$.

2) Perkembangan motorik halus anak prasekolah (4-6 tahun) termasuk kategori optimal sebanyak 52 orang $(86,7 \%)$ sedangkan untuk perkembangan motorik halus anak prasekolah (4-6 tahun ) dalam kategori tidak optimal sebanyak 8 orang ( $13,3 \%$ ). Kondisi ini menunjukkan bahwa proporsi anak untuk kategori tidak optima tergolong masih tinggi dan perlu melibatkan sekolah serta peran ibu untuk memberi pelatihan dan pembinaan dalam perkembangan motorik halus anak agar tercapai hasil yang optimal.

3) Ada hubungan antara tingkat pengetahuan ibu terhadap perkembangan anak prasekolah di TK Tunas Mekar I Desa Tegaljadi Marga Tabanan, yang ditandai dengan nilai Chi kuadrat $\left(\chi^{2}\right)$ hitung yang lebih besar dari pada nilai
Chi kuadrat $\left(\chi^{2}\right)$ tabel, dimana $\chi^{2}$ hitung $=36,923$ dan $\chi^{2}$ tabel $=3,481$. Untuk tingkat hubungan kedua variabel termasuk kategori kuat, yang ditandai dengan nilai koefisien kontingensi (C) sebesar 0,617.

\section{REFERENSI}

Arikunto. 2010.Prosedur Penelitian. Jogjakarta: Rineka Cipta

Depkes RI. 2010. Pedoman Pelaksanaan Stimulasi Deteksi Dini Tumbuh Kembang Anak Ditingkat Pelayanan Kesehatan Dasar.Jakarta:Depkes RI.

Dudley (2006) dalam dalam Rohmilia Kusuma. 2012. HUBUNGAN ANTARA TINGKAT PENGETAHUAN IBU TENTANG TUMBUH KEMBANG ANAK DAN PERKEMBANGAN MOTORIK HALUS BALITA DI WILAYAH KERJA PUSKESMAS PENUMPING SURAKARTA. Diunduh tanggal 4 Mei 2016 dari

http://eprints.ums.ac.id/18580/1

9/Naskah_publikasi.pdf

Gunarso, dkk. 2004. Psikologi Perkembangan Anak dan Remaja.Jakarta: BPK Gunung Mulia.

Hastuti (2010) dalam dalam Rohmilia Kusuma. 2012. HUBUNGAN ANTARA TINGKAT PENGETAHUAN IBU TENTANG TUMBUH KEMBANG ANAK DAN PERKEMBANGAN MOTORIK HALUS BALITA DI WILAYAH KERJA PUSKESMAS PENUMPING SURAKARTA. Diunduh tanggal 4 Mei 2016 dari

http://eprints.ums.ac.id/18580/1 9/Naskah_publikasi.pdf

Herlina (2010) dalam dalam Rohmilia Kusuma. 2012. HUBUNGAN ANTARA TINGKAT 


\section{PENGETAHUAN IBU \\ TENTANG TUMBUH \\ KEMBANG ANAK DAN \\ PERKEMBANGAN MOTORIK \\ HALUS BALITA DI WILAYAH \\ KERJA PUSKESMAS \\ PENUMPING SURAKARTA. \\ Diunduh tanggal 4 Mei 2016 \\ dari \\ http://eprints.ums.ac.id/18580/1 \\ 9/Naskah_publikasi.pdf}

Mansur. 2009.Psikologi Ibu dan Anak

untuk Kebidanan.Jakarta:

Salemba Medika.

Muliadi. 2011.Merangsang Kecardasan Anak.

http://www.ibudanbalita.com.

Diunduh tanggal 20 Maret 2012.

Narendra (2008) dalam dalam Rohmilia

Kusuma. 2012. HUBUNGAN

ANTARA TINGKAT

PENGETAHUAN IBU

TENTANG TUMBUH

KEMBANG ANAK DAN

PERKEMBANGAN MOTORIK

HALUS BALITA DI WILAYAH

KERJA PUSKESMAS

PENUMPING SURAKARTA.

Diunduh tanggal 4 Mei 2016

dari

http://eprints.ums.ac.id/18580/1

9/Naskah_publikasi.pdf

Nuraeni (2006) dalam dalam Rohmilia

Kusuma. 2012. HUBUNGAN

ANTARA

TINGKAT

PENGETAHUAN IBU

TENTANG TUMBUH

KEMBANG ANAK DAN

PERKEMBANGAN MOTORIK

HALUS BALITA DI WILAYAH

KERJA PUSKESMAS

PENUMPING SURAKARTA.

Diunduh tanggal 4 Mei 2016

dari

http://eprints.ums.ac.id/18580/1

9/Naskah_publikasi.pdf
Notoatmojo. 2010.Metodologi Penelitian Kesehatan.Jakarta : Rineka Cipta.

Nursalam. 2005. Asuhan Keperawatan Bayi dan Anak. Jakarta: Salemba Medika.

Purwadarminto. 2003. Kamus Besar Bahasa Indonesia. Jakarta :Balai Pustaka.

Riwidikdo. 2010. Statistik Kesehatan. Yogyakarta : Mitra Cendikia.

Soetjiningsih. 2002. Tumbuh Kembang Anak. Jakarta: EGC.

Sugiono. 2010. Statistik untuk Penelitian. Bandung: Alfabeta.

Taufik. 2006. Pendidikan Anak Prasekolah. Jakarta: Salemba Medika.

Wijaya.2011. Kesehatan Anak. http://www.idai.or.id__Diunduh tanggal 20 Maret 2012. 